\title{
Investigation on antifungal metabolites of Chinese caterpillar fungus Ophiocordyceps sinensis (Berk.) against wilt causing pathogen, F usarium spp.
}

\author{
S.B. Akshaya, A.S. Krishnamoorthy , C. Sangeetha, S. Nakkeeran and G. Thiribhuvanamala \\ Department of Plant Pathology, Tamil Nadu Agricultural University, Coimbatore - 641003, Tamil Nadu, India
}

\section{Article Info}

Article history

Received 6 March 2021

Revised 20 April 2021

Accepted 21 April 2021

Published online 30 June 2021

\section{Keywords}

Antifungal activity

Bioactive compounds

Ophiocordyceps sinensis (Berk.)

GC-MS

Chitinase gene

\begin{abstract}
Soil-borne diseases pose a major threat to the production of both agricultural and horticultural crops. Fusarium genus is one of the common soil-borne fungi which causes wilt disease with typical symptoms of yellowing, stunting, and wilting and leads to even 100 per cent yield loss under severe conditions. Owing to the residual effects of fungicides and pesticides, eco-friendly approaches are the current focus of researchers all over the globe. Ophiocordyceps sinensis (Berk.) G.H. Sung and his team popularly called as Chinese caterpillar fungus is an entomophagous fungus that belongs to the phylum Ascomycota secretes secondary metabolites known to possess antimicrobial properties and used in medicine. In this view, the present study was formulated to tap antimicrobial metabolites from O. sinensis against Fusarium spp. The ethyl acetate and methanolic fractions of cell-free culture filtrate (18 days old) of $O$. sinensis at a concentration of $3000 \mathrm{ppm}$ showed maximum inhibition of mycelial growth of Fusarium oxysporum $\mathrm{f}$. sp. lycopersici (43.10 and 46.6 per cent, respectively), followed by Fusarium oxysporum f.sp. cubense (42.20 and 41.10 per cent, respectively), when tested by poisoned food technique. Similarly, the methanolic and ethyl acetate fraction of $O$. sinensis of CFC condensate tested at higher concentrations of $9000 \mathrm{ppm}$ by paper disc assay, showed maximum inhibition of $F$. o f.sp cubense (72.20 and 70.20 per cent, respectively), followed by $F$. of. sp lycopersici (61.10 and 66.60 per cent, respectively). Characterization of antimicrobial metabolites of the methanolic fraction of CFC of $O$. sinensis through GC-MS analysis indicated the presence of twelve different compounds. Among these, n-decanoic acid, glycerin, and 1, 2, 3-benzenetriol was expressed with the highest peak area percentage which might be responsible for antifungal activity. Chitinase gene expression evidenced with the expression of amplicon size of $1047 \mathrm{bp}$ indicates that $O$. sinensis may also play a major role as a biocontrol agent. This study paves the way for identifying the antifungal compounds of $O$. sinensis against Fusarium spp.
\end{abstract}

\section{Introduction}

Ophiocordyceps sinensis (Berk.) G.H. Sung and his team popularly called summer grass and winter worm or caterpillar fungus (Cooke, 1892), is an entomophagous fungus, which belongs to the phylum Ascomycota. The fungus parasitizes larvae of ghost moths (Lepidoptera) or Thitarodes (Hepialus spp) moths. The erstwhile known anamorphic state of the genus Cordyceps, viz., Beauveria, Metarhizium, and Paecilomyces have been reported as biocontrol agents against insect pests and nematodes. It is one of the most valuable medicinal fungus known by pharmaceutical industries which helps in curing various diseases and its metabolites act as antibacterial, immunomodulatory (Zhong et al., 2009), immunosuppressive (Dong and Yao, 2011), anticomplementary (Zhou et al., 2009), antitumor, anti-inflammatory, antioxidant, antidiabetes, antifatigue, and antiaging. It also possesses various biologically active compounds like cordycepin (Zhou et al., 2009), polysaccharide (Zhong et al., 2009 and Dong and Yao, 2011), adenosine (Zhang et al., 2010), ergosterol (Das et al., 2010),

Corresponding author: Dr. A.S. Krishnamoorthy

Professor (Plant Pathology), Tamil Nadu Agricultural University, Coimbatore-641003, Tamil Nadu, India

E-mail: milkmushapk2@gmail.com

Tel.: +91-9790499006

Copyright (c) 2021 Ukaaz Publications. All rights reserved.

Email: ukaaz@yahoo.com; Website: www.ukaazpublications.com cordymin (Shrestha et al., 2012) and ethyne and ergotamine (Sangeetha et al., 2015b). Although, there is little work studied in Ophiocordyceps spp. against plant pathogens. More fascinatingly, Cordyceps sobolifera has been used as a potential biocontrol agent against Colletotrichum gleosporioides and Cochilobolus miyabeanus (Imtiaj and Lee, 2007). Varughese et al. (2012) reported that the two antifungal depsidones cordycepsidone $\mathrm{A}$ and cordycepsidone $\mathrm{B}$ isolated from $C$. dipterigena being antagonistic to Giberella fujikori. Sangeetha et al. (2015a) reported the antimicrobial activity of culture filtrates of $O$. sinensis against $F$. oxysporum f. sp. lycopersici and $F$. oxysporum f. sp. cubense. Despite its greater potential, the fungus, $O$. sinensis has not been explored properly in agrochemical industries. In this present investigation, experiments were carried out to study the antifungal activities of biomolecules from $O$. sinensis.

\section{Materials and Methods}

\subsection{Collection of fungal cultures}

Pure cultures of Ophiocordyceps sinensis, Fusarium oxysporum f. sp. lycopersici (Sacc.) Synder and Hansen, Fusarium oxysporum $\mathrm{f}$. sp. cubense, Fusarium ciceri, F. oxysporum, Fusarium spp. were obtained from the culture collection facility available in the Department of Plant Pathology, TNAU, Coimbatore. 
2.2 Extraction of bioactive compounds of $O$. sinensis using different solvents

Four mycelial discs measuring $6 \mathrm{~mm}$ diameter each, cut from the margin of a $5 \mathrm{~d}$ old colony of $O$. sinensis, were inoculated to $100 \mathrm{ml}$ of sterilized sabouraud dextrose agar (SDAY) broth (adjusted to $\mathrm{pH}$ 5.5) taken in $250 \mathrm{ml}$ conical flasks. The flasks were later placed on a rotary shaker at $120 \mathrm{rpm}$ and incubated at $25^{\circ} \mathrm{C}$ in darkness for 18 days. After incubation, the culture filtrate and the mycelial mat were separated by filtration through Whatman No. 40 filter paper. The filtrate was further centrifuged at $10,000 \mathrm{rpm}$ and the mycelium free culture filtrate was extracted with organic solvents, viz., methanol, ethanol, and ethyl acetate, (v/v) sequentially. The organic extracts of each solvent were evaporated separately under reduced pressures using a rotary evaporator at $40^{\circ} \mathrm{C}$. The condensate of each solvent was dried and dissolved in methanol $(1 \mathrm{mg} / \mathrm{ml})$ and filtered with a membrane filter $(0.2 \mu \mathrm{m})$ and stored at $4{ }^{\circ} \mathrm{C}$ for further study.

\subsection{Testing of secondary metabolites extracted with different solvents}

The antimicrobial activity of each solvent fraction of $O$. sinensis was evaluated by poison food technique. Crude extracts of CFC filtrate of different solvents fraction mixed separately with 1000 , 2000, 3000, 6000, and 9000 ppm with $100 \mathrm{ml}$ of sterilized molten PDA medium and poured into sterile petri plates and allowed to solidify. At the center of the poisoned medium, a $6 \mathrm{~mm}$ mycelial disc of the test pathogen was introduced and the petri plates were incubated at $28 \pm 2^{\circ} \mathrm{C}$. Constant observations were made and the per cent inhibition of mycelial growth of Fusarium f. sp. lycopersici, Fusarium f. sp. cubense, F. ciceri, and Fusarium spp. were recorded. The per cent inhibition was calculated by using the formula as proposed by Vincent (1927).

\subsection{Ethyl acetate and the methanolic fraction of CFC filtrates} of $O$. sinensis against Fusarium spp.

Based on the above studies, ethyl acetate and the methanolic fraction of CFC filtrate found effective at $3000 \mathrm{ppm}$ were again tested at higher concentrations. The inhibitory effect of ethyl acetate and the methanolic fraction of CFC filtrate of $O$. sinensis were evaluated by the paper disc assay method. Sterilized Whatman filter paper disc was immersed in crude extracts of the CFC filtrate of ethyl acetate and methanolic fractions at the concentration of 3000, 6000, $9000 \mathrm{ppm}$ and placed at one $\mathrm{cm}$ apart from four corners of sterilized petri plate containing PDA medium. The pathogen was placed at the center. The mycelial growth and zone of inhibition were recorded after $7 \mathrm{~d}$ of incubation. Based on the observations, a per cent reduction over control was calculated. Each dose was replicated three times. Sterile water used as a control was also maintained to assess the effect of bioactive molecules (Bauer et al., 1966). The per cent inhibition was calculated by using the formula as proposed by Vincent (1927).

2.5 Detection of bioactive molecules through gas chromatography mass spectrometry analysis (GC-MS)

Characterization of biomolecules of CFC filtrate condensate of $O$. sinensis (Methanolic fraction dissolved in DMSO) was done by GC-MS analysis. The column Elite-5MS (100 per cent Dimethylpolysiloxane), $30 \times 0.25 \mathrm{~mm} \times 0.25 \mu \mathrm{m}$ df equipped with GC Clarus 500 Perkin elmer and turbo mass - gold - Perkin - Elmer detector was used. The carrier gas (helium) flow rate was one $\mathrm{ml}$ per min, split 10:1 and injected volumes were two $\mu$. The column temperature was maintained initially at $110^{\circ} \mathrm{C}$ at the rate of $10^{\circ} \mathrm{C} / \mathrm{min}$ followed by increasing up to $280^{\circ} \mathrm{C}$ at the rate of $5^{\circ} \mathrm{C} / \mathrm{min}$ and hold time 9 min. The injector temperature was set at $250^{\circ} \mathrm{C}$ and was kept constant for $36 \mathrm{~min}$. The electron impact energy was $70 \mathrm{eV}$, Julet line temperature was set at $2000^{\circ} \mathrm{C}$ and the source temperature was set at $200^{\circ} \mathrm{C}$. Electron impact (EI) mass scan (m/z) was recorded in the 45-450 aMU range. Using computer searches on the NIST Ver. 2011 MS data library and comparing the spectrum obtained through GC-MS the compounds present in the sample were identified.

\subsection{Chitinase gene expression of $O$. sinensis}

The genomic DNA of $O$. sinensis was subjected for PCR amplification using a range of primer pairs, Bbchit115'CCCTTCTACCCTTGACTTGTTC-3' and Bbchit1-2 5'TAT CTACAAATATGTACCAAC-3' for the detection of the chitinase gene. PCR was performed in a thermocycler (Eppendorf-Master Cycler nexus gradient S-Eppendorf, A.G, Hamburg, Germany) by using the conditions included $5 \mathrm{~min}$ preheating step at $95^{\circ} \mathrm{C}$ followed by 35 cycles consisting of denaturation at $95^{\circ} \mathrm{C}$ for $30 \mathrm{sec}$, annealing at $60^{\circ} \mathrm{C}$ for $30 \mathrm{sec}$, extension at $72^{\circ} \mathrm{C}$ for $2 \mathrm{~min}$ and followed by a final extension at $72^{\circ} \mathrm{C}$ for $10 \mathrm{~min}$.

\subsection{Statistical analysis}

All the experiments were performed in triplicate and the treatment means differences were evaluated with Duncan's Duncan's Multiple Range-Test (DMRT) at 5\% significance (Gomez and Gomez, 1984). The package used for analysis was IRRISTAT version 92-1 developed by the International Rice Research Institute Biometrics unit, the Philippines.

\section{Results}

\subsection{Testing the antifungal potential of $O$. sinesis against Fusarium spp.}

\subsubsection{Poisoned food technique}

Bioactive compounds were extracted from the CFC (Cell-free culture) filtrate condensate of $O$. sinensis $(18 \mathrm{~d}$ old $)$ with different solvents, viz., methanol, ethanol, ethyl acetate. The concentration of solvent fractions was adjusted to $1000 \mathrm{ppm}, 2000 \mathrm{ppm}$, and $3000 \mathrm{ppm}$ was represented in Figure 1. Among the solvents tested, the methanolic and ethyl acetate fractions of CFC filtrate condensate at $3000 \mathrm{ppm}$ showed the maximum mycelial inhibition of $F$. $o$. f.sp. cubense (42.20 and 41.10 per cent, respectively), F. $o$. f.sp. lycopersici (43.10 and 46.60 per cent, respectively), F. cicero (40.00 and 42.20 per cent, respectively), Fusarium spp. (41.10 and 40.00 per cent, respectively) and $F$. oxysporum ( 35.50 and 43.30 per cent, respectively), followed by $2000 \mathrm{ppm}$, the mycelial inhibition of $F$. $o$. f.sp. cubense (40.00 and 41.11 per cent, respectively), F. o. f. sp. lycopersici (41.10 and 44.4 per cent, respectively), F. ciceri (40.00 and 42.20 per cent, respectively Fusarium spp. (44.40 and 37.70 per cent, respectively) and $F$. oxysporum (33.50 and 43.30 per cent, respectively). 


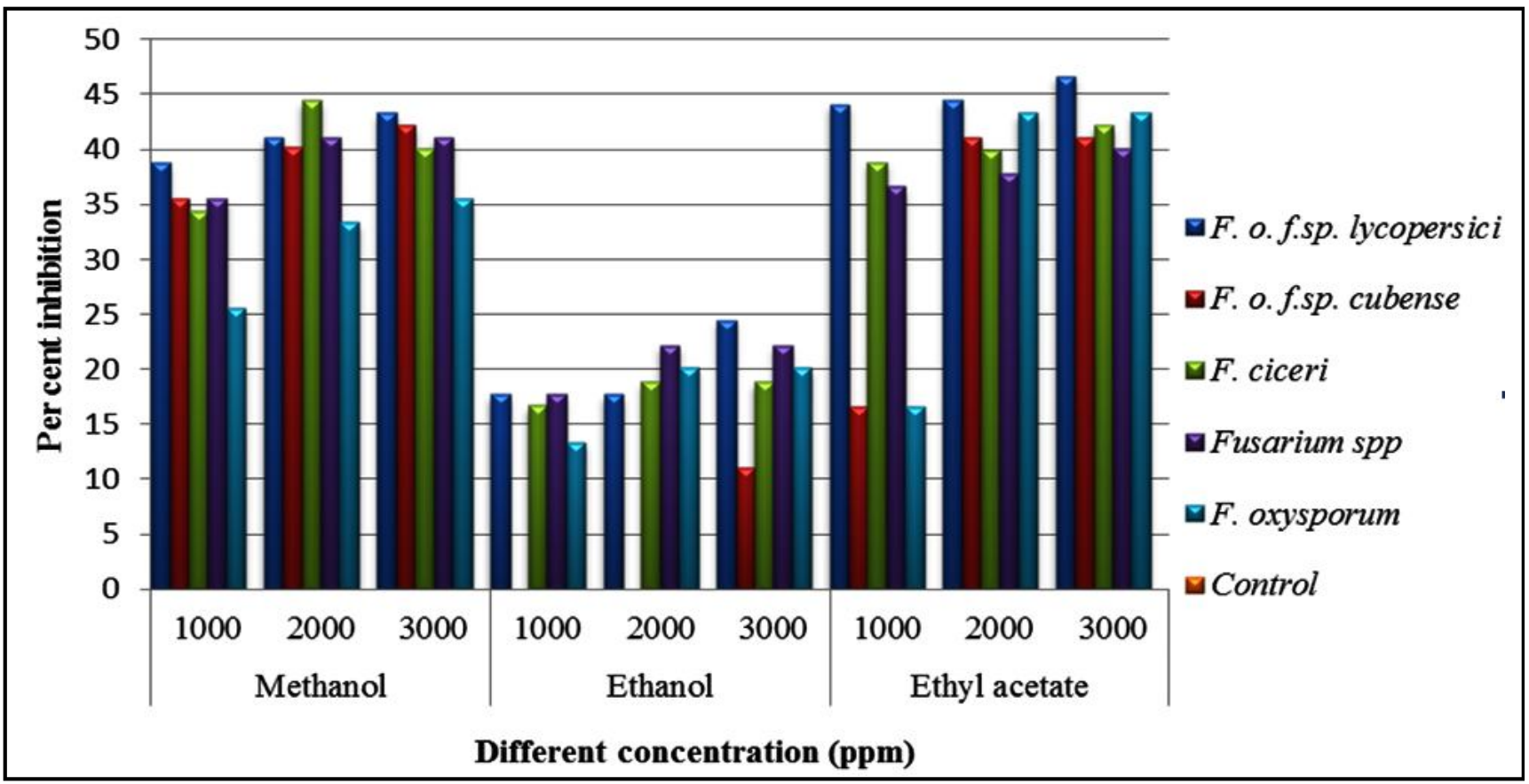

Figure 1: Effect of the different solvent fraction of $O$. sinensis against Fusarium spp.

In the case of methanolic and ethyl acetate fractions of CFC filtrate condensate, a concentration of 1000 ppm showed the minimum mycelial inhibition of $F$. $o$. f. sp. cubense (35.5 and 16.60 per cent, respectively), $F$. $o$. f. sp. lycopersici (38.80 and 41.10 per cent, respectively), $F$. ciceri (34.00 and 38.80 per cent, respectively), Fusarium spp. (35.50 and 36.60 per cent, respectively), F. oxysporum (16.60 and 25.50 per cent, respectively). The ethanolic fraction of culture filtrate condensate in 1000,2000 , and $3000 \mathrm{ppm}$ concentration showed the lowest mycelial inhibition of $F$. $o$. f. sp. cubense $(0.00$, 0.00 and11.11 per cent, respectively), $F$. $o$. f. sp. lycopersici(17.70, 17.71 and 24.40 per cent, respectively), F. ciceri $(16.60,18.80$ and 18.80 per cent, respectively), Fusarium spp. (17.70, 22.20 and 22.20 per cent, respectively) and $F$. oxysporum $(13.30,20.00$ and 20.00 per cent, respectively). Also, further study to confirm the above assay methanolic and ethyl acetate fraction was tested against $F$. $o$. f. sp. lycopersici and $F$. o. f. sp. cubense at higher concentrations.

\subsubsection{Paper disc assay}

The methanolic and ethyl acetate fractions of $O$. sinensis CFC condensate tested by paper disc assay showed the maximum inhibition in $F$. $o$. f. sp. cubense $(72.20$ and 70.20 per cent, respectively) followed by $F$. $o$. f. sp. lycopersici (61.10 and 66.60 per cent, respectively) at a concentration of $9000 \mathrm{ppm}$, followed by $6000 \mathrm{ppm}$ which showed the inhibition of in $F$. $o$. f. sp. cubense (61.10 and 55.50 per cent), followed by $F$. $o$. f. sp. lycopersici (53.30 and 54.40 per cent respectively). The minimum inhibition was noticed at the concentration of $3000 \mathrm{ppm}$ in $F$. o. f. sp. cubense (42.20 and 44.40 per cent), followed by $F$. $o$. f. sp. lycopersici (35.80 and 40.00 per cent, respectively) in methanolic fraction (Table 1 ; Figure 2). The result of current investigation conclusively indicated non-polar solvents methanol could be effectively used for extraction of bioactive compounds from $O$. sinensis compared to other solvents.

Table 1: Testing of ethyl acetate and methanolic fractions of CFC filtrate condensate of $O$. sinensis against Fusarium spp.

\begin{tabular}{|c|c|c|c|c|c|}
\hline \multirow{2}{*}{$\begin{array}{l}\text { Fraction of bioactive } \\
\text { molecules }\end{array}$} & \multirow{2}{*}{$\begin{array}{c}\text { Concentrations } \\
\text { (ppm) }\end{array}$} & \multicolumn{2}{|c|}{ F. o. f. sp. lycopersici } & \multicolumn{2}{|c|}{ F. o. f. sp. cubense } \\
\hline & & Growth (mm) & PI & Growth (mm) & PI \\
\hline \multirow[t]{3}{*}{ Ethyl acetate fraction } & 3000 & $58.00(50.06)$ & $35.80^{f}(36.75)$ & $52.00(46.49)$ & $42.20^{f}(40.45)$ \\
\hline & 6000 & $42.00(40.39)$ & $53.30^{\mathrm{d}}(46.89)$ & $35.00(35.57)$ & $61.10^{c}(51.45)$ \\
\hline & 9000 & $35.00(36.27)$ & $61.10^{\mathrm{b}}(51.41)$ & $25.00(30.17)$ & $72.20^{\mathrm{a}}(58.18)$ \\
\hline \multirow[t]{3}{*}{ Methanolic fraction } & 3000 & $54.00(47.29)$ & $40.00^{\mathrm{e}}(39.23)$ & $50.00(38.52)$ & $44.40^{\mathrm{e}}(41.78)$ \\
\hline & 6000 & $41.00(39.81)$ & $54.40^{c}(47.29)$ & $40.00(38.12)$ & $55.50^{\mathrm{d}}(48.15)$ \\
\hline & 9000 & $30.00(33.21)$ & $66.60^{\mathrm{a}}(54.69)$ & $27.00(31.98)$ & $70.00^{\mathrm{b}}(56.79)$ \\
\hline \multicolumn{2}{|l|}{ Control } & 90.00 & 0.00 & 90.00 & 0.00 \\
\hline \multicolumn{2}{|l|}{$C D(p=0.05)$} & 1.49 & - & 1.27 & - \\
\hline
\end{tabular}




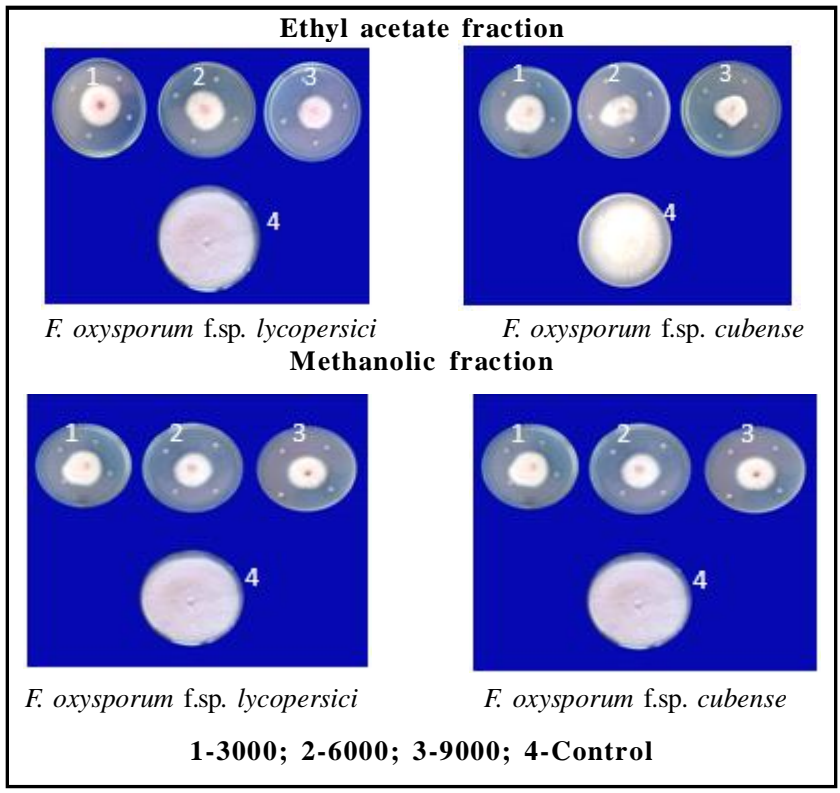

Figure 2: Effect of ethyl acetate and methanolic fractions of CFC condensate of $O$. sinensis against Fusarium spp.
3.3 Profiling of volatile organic compounds (VOCs) of $O$. sinensis through GC-MS

The methanolic fraction of CFC filtrate condensate was subjected to GC-MS analysis. The identity of compounds was confirmed through the NIST library 2011 and the AMDIS software program. The results showed an array of biomolecules as presented in Table 2 and Figure 2.

Twelve different compounds, viz., hydroxylamine; glycerin; 4Hpyran-4-one, 2, 3-dihydro-3, 5-dihydroxy-6-methyl; dianhydroma nnitol; mexiletine; methyl eugenol; 1,2,3-Benzenetriol; cyclopropane, nonyl; cyclohexane-1,4,5-triol-3-one-1-carboxylic acid; 2-(allylamino)-5-ethyl-1,3,4-thiadiazole; cyclopropane, 1,2dibutyl and n-decanoic acid have been detected. Among the 12 compounds, the highest peak area was observed with n-decanoic acid (32.95 per cent) at $24.398 \mathrm{RT}$, followed by glycerin ( 10.67 per cent) at $10.92 \mathrm{RT}$ and 1, 2, 3-benzenetriol (5.24 per cent) at a retention time of 18.893 (Figure 3 and Table 2).

\subsection{Chitinase gene expression}

In this present study, the presence of chitinase producing gene was identified by the PCR analysis using gene-specific primer indicate the name of the primer $O$. sinensis contained chitinase producing gene, which was amplified at 1047 bp (Figure 3).

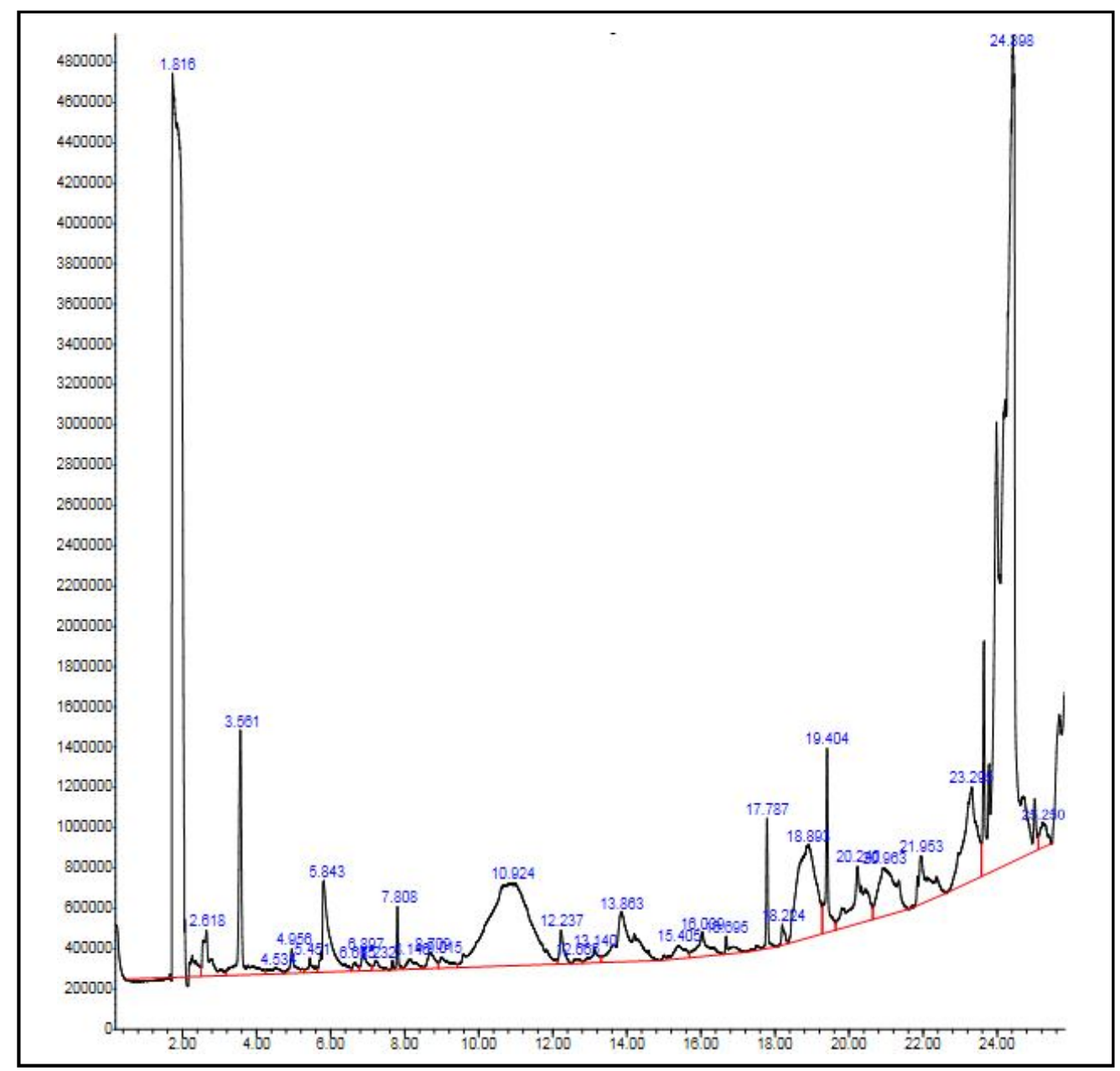

Figure 3: Chromatogram of methanolic extract of CFC filtrate condensate of $O$. sinensis. 


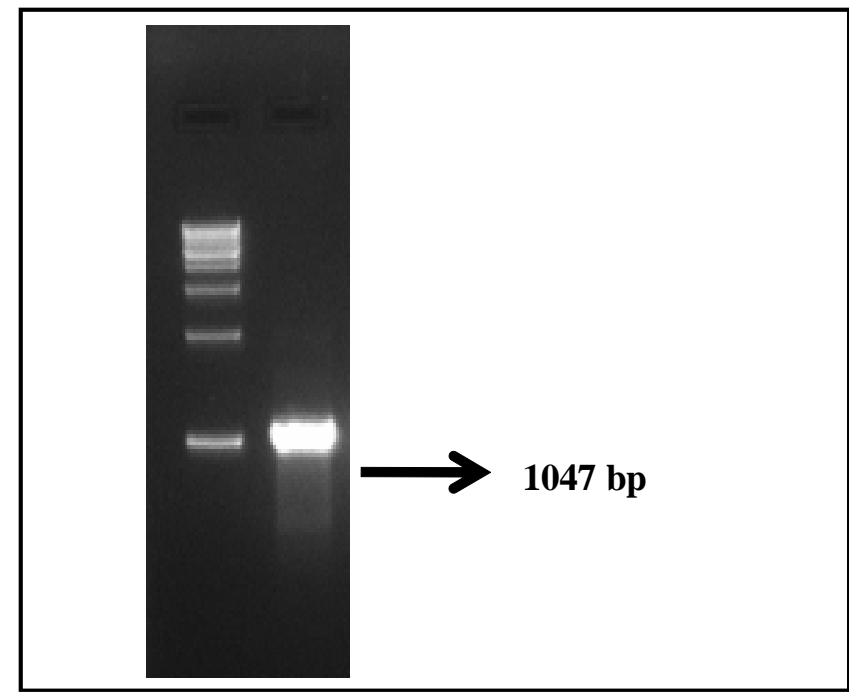

Figure 4: PCR amplification of Chitinase gene expression of O. sinensis.

\section{Discussion}

Bioactive compounds were found to be diversely distributed in the cell-free culture filtrate of $O$. sinensis. Among the different solvents used for extraction and recovery of bioactive compounds, ethyl acetate and methanolic fractions of CFC condensate had exhibited considerable antifungal activity (Kumar et al., 2013). In the present study, the methanolic extract of cell-free culture filtrate of $O$. sinensis produced diverse groups of potential biologically active compounds against Fusarium spp. It is observed that Cordyceps sp. had inhibited the mycelial growth of $R$. solani followed by A. brassicae, $F$ oxysporum, Sclerotium rolfsii, and Sclerotium sclerotiorum (Pandey, 2012). The ethanolic extract of non-edible macrofungi Stereum ostrea had contained antifungal properties against Colletotrichum gloeosporioides, C. miyabeanus, and Botrytis cinerea Imtiaj and Lee, (2007). Similarly, in our study, the methanolic and ethyl acetate fractions of cell-free culture filtrate of $O$. sinensis effectively inhibits the mycelial growth of $F$. oxysporum f.sp. lycopersici followed, by $F$. oxysporum f.sp cubense which was found to be significantly different from other Furasium spp at the concentration of $3000 \mathrm{ppm}$. The paper disc assay demonstrated that the CFC condensate of $O$. sinensis dissolved in ethyl acetate and methanolic fraction showed that the maximum inhibition was observed in $F$. o. f. sp cubense (72.2 per cent and 70.02 per cent), followed by $F$. $o$. f. sp lycopersici $(61.10$ and 66.60 per cent respectively), at a concentration of $9000 \mathrm{ppm}$ which was significantly different from the other concentrations tested. Ahamad, (2012) reported that the crude ethyl acetate extract of $B$. bassiana had exhibited moderate antifungal activity at concentrations between 1200 and $1600 \mu \mathrm{g} / \mathrm{ml}$ against A. tenuis, $F$. avenaceum, and F. graminearum by paper disc assay. Chen and Huang, (2010) also tried the paper disc agar diffusion method to test the effect of 27 culture filtrates from 14 species of edible mushroom fungi tested against, viz., Colletotrichum higgisianum, Phytophthora capsici, Fusarium oxysporum f.sp. lactuca, Alternaria brassicola, Rhizoctonia solani, and Pythium aphanidermatum and found that the CFC of Agaricus bisporus slightly suppressed the mycelial growth of Alternaria brassicola $(37.3 \%)$ and weakly inhibited the mycelial growth of Colletotrichum higginsianum, Fusarium oxysporum f.sp lactuca, and Phytophthora capsici when compared to others. Furthermore, in our investigation, GC-MS was employed to identify the antifungal compounds.

Table 2: GC-MS analysis of the methanolic fraction of CFC filtrate condensate* (18 d old) of $O$. sinensis

\begin{tabular}{|c|c|c|c|c|c|}
\hline RT* & Compound & $\begin{array}{l}\text { Molecular } \\
\text { formula }\end{array}$ & $\begin{array}{c}\text { Molecular weight } \\
(\mathrm{g} / \mathrm{mol})\end{array}$ & Mode of action & Reference \\
\hline 10.92 & Glycerin & $\mathrm{C}_{3} \mathrm{H}_{8} \mathrm{O}_{3}$ & 92.09 & Defense response & Li et al. (2016) \\
\hline 12.23 & 4H-Pyran-4-one & $\mathrm{C}_{6} \mathrm{H}_{8} \mathrm{O}_{4}$ & 144.0 & Antimicrobial activity & Dahpour et al. (2012) \\
\hline 13.86 & Dianhydromannitol & $\mathrm{C}_{6} \mathrm{H}_{10} \mathrm{O}_{4}$ & 146.0 & Antimicrobial & Rajeswari et al. (2013) \\
\hline 15.40 & Mexiletine & $\mathrm{C}_{11} \mathrm{H}_{17} \mathrm{NO}$ & 179.0 & Antiarrhythmic agent & Labbe et al. (2003) \\
\hline 17.78 & Methyleugenol & $\mathrm{C}_{11} \mathrm{H}_{14} \mathrm{O}_{2}$ & 178.0 & Antifungal agent & Choi et al. (2010) \\
\hline 18.89 & 1,2,3-Benzenetriol & $\mathrm{C}_{6} \mathrm{H}_{6} \mathrm{O}_{3}$ & 126.0 & $\begin{array}{l}\text { Fungicidal and } \\
\text { insecticidal } \\
\text { properties }\end{array}$ & $\begin{array}{l}\text { Euginamala and Jeyaraj, } \\
\text { (2014) }\end{array}$ \\
\hline 19.40 & Cyclopropane, nonyl & $\mathrm{C}_{3} \mathrm{H}_{6}$ & 42.08 & $\begin{array}{l}\text { Biopesticidal } \\
\text { properties }\end{array}$ & Praveen Kumar et al. (2010) \\
\hline 20.96 & $\begin{array}{l}\text { Cyclohexan-1,4,5-triol- } \\
\text { 3-one-1-carboxylic acid }\end{array}$ & $\mathrm{C}_{7} \mathrm{H}_{10} \mathrm{O}_{6}$ & 190.15 & $\begin{array}{l}\text { Pharmacheutical } \\
\text { applications }\end{array}$ & Praveen kumar et al. (2010) \\
\hline 21.95 & $\begin{array}{l}\text { 2-(Allylamino)-5-ethyl- } \\
\text { 1,3,4-thiadiazole }\end{array}$ & $\mathrm{C}_{4} \mathrm{H}_{7} \mathrm{~N}_{3} \mathrm{~S}$ & 129.19 & $\begin{array}{l}\text { Anti-microbial and } \\
\text { anti-inflammatory }\end{array}$ & Popiolek et al. (2013) \\
\hline 24.39 & n-Decanoic acid & $\mathrm{C}_{10} \mathrm{H}_{20} \mathrm{O}_{2}$ & 172.0 & $\begin{array}{l}\text { Nematicidal and } \\
\text { pesticidal properties }\end{array}$ & Praveen Kumar et al. (2010) \\
\hline
\end{tabular}

The results indicated that the presence of twelve compounds and its antifungal nature of the compounds were analyzed. Among these, n- decanoic acids, glycerin, and 1, 2, 3-benzenetriol were expressed with the highest peak area per cent which might be responsible for antifungal 
activity n-decanoic acid belongs to the class medium-chain fatty acid has possessed nematicidal and pesticidal properties (Praveen Kumar et al., 2010). Popiolek et al. (2013) illustrated that 2-(allylamino)5-ethyl-1, 3, 4-thiadiazole had possessed a wide range of biological activities including antimicrobial and anti-inflammatory activities. Glycerin is an organo-oxygen compound reported with antibacterial, antioxidant, hypo-cholesterolemic activity and also has a defense response against plant pathogens (Li et al., 2016). Another compound, namely; 1, 2, 3-benzenetriol and its derivatives 1, 3, 5-benzenetriol pyrogallol compound are aromatic alcoholic compounds known for fungicidal, insecticidal, antioxidant, and antiseptic activities (Euginamala and Jeyaraj, 2014). Terpenoid and steroid molecules such as cyclopropane, 1, 2-dibutyl, cyclohexan-1, 4, 5-triol-3-one1 -carboxylic acid, and cyclopropane, nonyl has several pharmaceutical and biopesticidal applications (Praveen Kumar et al., 2010). Other compounds like methylene chloride, oxime, methoxy-phenyl, mexiletine, 4H-pyran-4-one, 2, 3-dihydro-3, 5-dihydroxy-6-methyl detected from $O$. sinensis preparations have been reported to possess antimicrobial, biopesticidal, and pharmaceutical properties (Dahpour et al., 2012; Janani and Singaravadivel, 2014).

Fungal chitinases have been exploited in the development of biocontrol strategies against insects, fungi, or nematodes (Seidl, 2008; Leger and Wang 2010). Fungi are known to possess various chitin degrading enzymes with an average of 10-20 different chitinases; where chitinases play diverse biological roles, such as cell-wall remodeling, nutrient scavenging, and aggressive functions (Seidl, 2008; Xu et al., 2011; Hartl et al., 2012 and Hamid et al., 2013). Over expression of Bbchitl was able to increase the ability of Beauveria (Cordyceps) bassiana to digest insect cuticle, resulting in increased virulence against insects (Murad et al., 2007). Similarly, in our study, O. sinensis is known to produce chitinase genes which might be responsible for defense response against phytopathogens. Chantasingh et al. (2011) reported that O. unilateralis express chitinase (Ouchi) full-length gene (1311 bp) encodes 436 amino acids with the first 20 amino acids as a putative signal peptide. The chitinase expression also enhanced fungal toxicity to another organism. The mature Ouchi gene was sub-cloned into an Agrobacterium and then transformed into B. bassiana. The expression of chitinase Ifu-chit2 in vivo suggests that the chitinase may play a role in the early stage of pathogenesis (Meng et al., 2015). With this background, it is concluded that the chitinase produced by $O$. sinensis may also play a major role in hydrolyses of chitin in insects for further colonization and production of fruiting bodies.

\section{Conclusion}

The present study revealed that the methanolic and ethyl acetate fraction of cell-free condensate of $O$. sinensis could inhibit the mycelial growth of Fusarium spp. Further, characterization of the methanolic extracts of CFC through GC-MS concealed the presence of more antifungal metabolites. Interestingly, the presence of chitinase-producing genes in $O$. sinensis offers scope for use as biocontrol agents. The results obtained from this study will certainly paves way for the exploration of bioactive compounds for the development of ecofriendly fungicidal formulations from Ophiocordyceps spp against plant pathogens.

\section{Acknowledgments}

The authors thank the University for providing the facilities through the fund support obtained from UGC- SAP- DRS 1 on Mushroom Biotechnology and All India Co-ordinated Research Project on Mushroom to carry out the research work.

\section{Conflict of interest}

The authors declare that there are no conflicts of interest relevant to this article.

\section{References}

Balakumar, R.; Sivaprakasam, E.; Kavitha, D.; Sridhar, S. and Kumar, J. S. (2011). Antibacterial and antifungal activities of fruit bodies of Phellinus mushroom extract. Int. J. Biosci., 1(3):72-77.

Chantasingh, D.; Kitikhun, S.; Eurwilaichitr, L.; Uengwetwanit, T. and Pootanakit, K. (2011). Functional expression in Beauveria bassiana of a chitinase gene from Ophiocordyceps unilateralis, an ant-pathogenic fungus. Biocontrol Sci. Technol., 21(6):677-686.

Chen, Y.Q.; Hu, B.; Xu, F.; Zhang, W.; Zhou, H. and Qu, L. H. (2004). Genetic variation of Cordyceps sinensis, a fruit-body-producing entomopathogenic species from different geographical regions in China. FEMS Microbiol. Lett., 230(1):153-158.

Choi, Y.K.; Cho, G.S.; Hwang, S.; Kim, B.W.; Lim, J.H.; Lee, J.C.; Kim, H.C.; Kim, W.K. and Kim, Y.S. (2010). Methyleugenol reduces cerebral ischemic injury by suppression of oxidative injury and inflammation. Free Radic. Res., 44(8):925-935.

Cooke, M.C. (1892). Vegetable wasps and plant worms: A popular history of entomogenous fungi, or fungi parasitic upon insects. Society for Promoting Christian Knowledge.

Dahpour, A. A.; Rahdari, P. and Sobati, Z. (2012). Chemical composition of essential oil, antibacterial activity, and brine shrimp lethality of ethanol extracts from Sedum pallidum. J. Medi. Plants Res., 6(16): 3105-3109.

Das, S. K.; Masuda, M.; Hatashita, M.; Sakurai, A. and Sakakibara, M. (2010). Optimization of culture medium for cordycepin production using Cordyceps militaris mutant obtained by ion beam irradiation. Proc. Biochem., 45:129-132.

Dennis, D. and Webster, J. (1971a). Antagonistic properties of species - groups of Trichoderma. II. Production of volatile antibiotics. Trans. Br. Mycol. Soc., 57(1):41-48.

Dong, C. H., and Yao, Y. J. (2011). On the reliability of fungal materials used in studies on Ophiocordyceps sinensis. J. Ind. Microbiol. Biotechnol., 38: $1027-1035$.

Euginamala, V. and Jeyaraj, M. (2014). Determination of antibacterial, antifungal, bioactive constituents of Triphala by FT-IR and GCMS analysis. Int. J. Pharm. Pharm. Sci., 6:1-4.

Hamid, T.; Ahmad, M.; Malik, M.; Ahmad, M.Z; Abidin, Z. and Saleem, J. (2013). Purification and characterization on thermostable chitinase From A Novel S. Maltophilia Strains. Mal. J. Microbiol., 9(1):7-12.

Hartl, L.; Zach, S. and Seidl-Seiboth, V. (2012). Fungal chitinases: diversity, mechanistic properties, and biotechnological potential. Appl. Microbial. Biotechnol., 93(2):533-543.

Imtiaj, A. and Lee, T. S. (2007). Screening of antibacterial and antifungal activities from Korean wild mushrooms. World. j Agri. Sci., 3(3):316321.

Janani, S. R. and Singaravadivel, K. (2014). Screening of phytochemical and GC-MS analysis of some bioactive constituents of Asparagus racemosus. Int. J. Pharm Tech. Res., 6(2):428-432.

Labbe, L.; Abolfathi, Z.; Lessard, E.; Pakdel, H.; Beaune, P. and Turgeon, J. (2003). Role of specific cytochrome P450 enzymes in the N-oxidation of the antiarrhythmic agent mexiletine. Xenobiotica., 33(1):13-25. 
Leger, R. J. S. and Wang, C. (2010). Genetic engineering of fungal biocontrol agents to achieve greater efficacy against insect pests. Appl. Microbial. Biotechnol., 85(4):901-907.

Li, Y.; Song, N.; Zhao, C.; Li, F.; Geng, M.; Wang, Y.; Liu, W.; Xie, C. and Sun, Q. (2016). Application of glycerol for induced powdery mildew resistance in Triticum aestivum L. Front. Physiol., 7:413.

Martin, K.J. and Rygiewicz, P.T. (2005). Fungal-specific PCR primers developed for analysis of the ITS region of environmental DNA extracts. BMC Microbiol., 5(1):1-6.

Meng, H.; Wang, Z.; Meng, X.; Xie, L. and Huang, B. (2015). Cloning and expression analysis of the chitinase gene Ifu-chit2 from Isaria fumosorosea. Genet. Mol. Boil., 38(3):381-389.

Murad, A.M.; Laumann, R.A.; Mehta, A.; Noronha, E.F., and Franco, O.L. (2007) Screening and secretomic analysis of entomopathogenic Beauveria bassiana isolates in response to cowpea weevil (Callosobruchus maculatus) exoskeleton. Comp. Biochem. Physiol. C. Toxicol. Pharmacol., 145(3):333-338.

Pandey, V. K. (2012). Anti-plant pathogenic properties of higher fungi especially wild mushrooms. Ph.D. (Ag.) Thesis, Chaudhary Sarwan Kumar Himachal Pradesh Krishi Vishvavidyalaya, Palampur, India. $164 \mathrm{p}$

Paszota, P.; Escalante-Perez, M.; Thomsen, L.R.; Risor, M.W.; Dembski, A.; Sanglas, L.; Nielsen, T. A.; Karring, H.; Thogersen, I. B.; Hedrich, R. and Enghild, J.J. (2014). Secreted major venus flytrap chitinase enables digestion of arthropod prey. Biochim et Biophysica. Acta (BBA)-Prot. Proteom., 1844(2):374-383.

Popiolek, L.; Kosikowska, U.; Mazur, L.; Dobosz, M. and Malm, A. (2013). Synthesis and antimicrobial evaluation of some novel 1, 2, 4-triazole and 1, 3, 4-thiadiazole derivatives. Med. Chem. Res., 22(7):3134-3147.

Praveen Kumar, P., Kumaravel, S. and Lalitha, C. (2010). Screening of antioxidan activity, total phenolics, and GC-MS study Vitax negundo. Afric J. Biochem. Res., 4(7):191-195.

Rajeswari, G.; Murugan, M. and Mohan, V. R. (2013). GC-MS analysis of bioactive components of Hugonia mystax L. bark (Linaceae). J. Pharm. Biomed. Sci., 29:818-824
Sangeetha, C.; Krishnamoorthy, A. S. and Ramakrishnan, S. (2015b). Testing bioactive compounds of Chinese caterpillar fungus, Ophiocordyceps spp against Root-knot nematode Meloidogyne incognita. Res. J. Agri. Sci., 6(5):1129-1133.

Sangeetha, C.; Krishnamoorthy, A. S.; Nakeeran, S.; Ramakrishnan, S. and Amirtham, D. (2015a). Evaluation of bioactive compounds of Ophiocordyceps sinensis (Berk.) Sacc. against Fusarium spp. Biochem. Cell. Arch., 15(2):431-435.

Seidl, V. (2008). Chitinases of filamentous fungi: A large group of diverse proteins with multiple physiological functions. Fungal. Biol. Rev., 22(1):36-42.

Shrestha, B.; Zhang, W.; Zhang, Y. and Liu, X. (2012). The medicinal fungus Cordyceps militaris: research and development. Mycol. Prog., 11(3):599-614.

Varughese, T.; Rios, N.; Higginbotham, S.; Arnold, A.E.; Coley, P.D.; Kursar, T.A.; Gerwick, W.H. and Rios, L.C. (2012). Antifungal depsidone metabolites from Cordyceps dipterigena, an endophytic fungus antagonistic to the phytopathogen Gibberella fujikuroi. Tetrahed. Lett., 53(13): 1624-1626.

Vincent, J. M. (1927). Distortion of fungal hyphae in the presence of certain inhibitors. Nature., 159:850.

Xu, W.; Yang, S.; Bhadury, P.; He, J.; He, M.; Gao, L.; Hu, D. and Song, B. (2011). Synthesis and bioactivity of novel sulfone derivatives containing 2, 4-dichlorophenyl substituted 1, 3, 4-oxadiazole / thiadiazole moiety as chitinase inhibitors. Pestic. Biochem. Physiol., 101(1): 6-15.

Zhang, A.L.; Lu, J.H.; Zhang, N.; Zheng, D.; Zhang, G.R. and Teng, L.R. (2010). Extraction, purification, and antitumor activity of polysaccharide from mycelium of mutant Cordyceps militaris. Chemic. Res. Chin. Univers., 26(5):798-802.

Zhong, S.; Pan, H.; Fan, L.; Lv, G.; Wu, Y.; Parmeswaran, B.; Pandey, A. and Soccol, C.R. (2009). Advances in research of polysaccharides in Cordyceps species. Differences, 13:14.

Zhou, X.; Gong, Z.; Su, Y.; Lin, J. and Tang, K. (2009). Cordyceps fungi: natural products, pharmacological functions, and developmental products. J. Pharm. Pharmacol., 61(3):279-291. 